\title{
Microstructural characterization of pore types in unconventional gas reservoirs utilizing FEG-SEM: An example from the Galembo Member of the Cretaceous La Luna Formation, Middle Magdalena Valley Basin (Colombia)
}

\author{
Carlos A. Ríos ${ }^{1, *}$, Oscar M. Castellanos², Efraín Casadiego Q ${ }^{1}$ \\ ${ }^{1}$ Grupo de Investigación en Geología Básica y Aplicada (GIGBA), Escuela de Geología, Universidad Industrial de Santander, Colombia \\ ${ }^{2}$ Grupo de Investigación en Geofísica y Geología (PANGEA), Programa de Geología, Universidad de Pamplona, Colombia
}

\begin{abstract}
Mineralogy and microstructure are key variables defining the physical properties of a rock. Mudstones show inherently heterogeneous matrix pore-size distributions. They can show organic and inorganic pores and the transport mechanism through pores is different, and, therefore, it is necessary to describe their organic and inorganic porosity. This work uses Field Emission Gun Scanning Electron Microscopy to characterize the Galembo Member mudstones, Cretaceous La Luna Formation, Middle Magdalena Valley Basin, Colombia. There are several pore types in mudstones, including interparticle pores due to flocculation of clay minerals, organoporosity due to burial and thermal maturity of organic matter, intraparticle pores from organisms, intraparticle pores within mineral grains, and microchannels and microfractures, including dissolution, fillings and interlayer fractures. The existence of interconnected pores in such complex fracture-pore system provides effective pathways for primary gas migration and it also provides a storage space for the residual petroleum in mudstones, which is important for the primary migration and storage for mudstone gas resources. The pore connectivity is high and increases towards the top of the Galembo Member.
\end{abstract}

Key words: Mudstones, microstructural, porosity, Galembo Member, La Luna Formation, Middle Magdalena Valley Basin, Colombia.

Caracterización microestructural de tipos de poros en reservorios no convencionales de gas utilizando MEBFEC: Un ejemplo del Miembro Galembo de la Formación La Luna del Cretáceo, Cuenca del Valle Medio del Magdalena (Colombia)

\begin{abstract}
Resumen
La mineralogía y la microestructura son variables claves que definen las propiedades físicas de una roca. Las lodolitas muestran distribuciones de tamaño de poro en la matriz inherentemente heterogéneas. Ellos pueden mostrar poros orgánicos e inorgánicos y el mecanismo de transporte a través de poros es diferente, y, por lo tanto, es necesario describir su porosidad orgánica e inorgánica. Este trabajo utiliza Microscopía Electrónica de Barrido de Fuente de Emisión de Campo para caracterizar las lodolitas del Miembro Galembo de la Formación La Luna del Cretácico, Cuenca del Valle Medio del Magdalena, Colombia. Hay varios tipos de poros en las lodolitas, incluyendo poros interpartículas debido a la floculación de minerales de arcilla, porosidad orgánica debida al enterramiento y madurez térmica de la materia orgánica, poros intrapartıculas de organismos, poros intrapartículas dentro de granos minerales, y microcanales y microfracturas, incluyendo disolución, relleno y fracturas entre capas. La existencia de poros interconectados en tal complejo sistema de poros-fracturas ofrece vías eficaces para la migración primaria de gas y también proporciona un espacio de almacenamiento para el petróleo residual en las lodolitas, lo cual es importante para la migración primaria y almacenamiento de los recursos de gas asociado a lodolitas. La conectividad entre poros es alta y aumenta hacia la parte superior del Miembro Galembo.
\end{abstract}

Palabras clave: lodolitas, microestructural, porosidad, Miembro Galembo, Formación La Luna, Cuenca del Valle Medio del Magdalena, Colombia.

\section{Introduction}

Recently, the energy industry is focusing on the unconventional resources, taking into account that they are an alternative promising source of hydrocarbon supply.
Traditionally, shale-gas systems have been considered as source rocks and seals of conventional reservoirs, are organically-rich, fine grained sedimentary rocks capable of producing commercially important quantities of 
hydrocarbons upon hydraulic fracturing, although extraction is further complicated by the tight, thinly layered nature of these rocks. A shale-gas system is an unconventional petroleum system in which the shale acts as both the source of, and the reservoir for, hydrocarbon gases that are derived from the organic matter within the shales through biogenic and/or thermogenic processes (e.g., Hill et al., 2007). The unconventional gas reservoirs are very important for the petroleum exploration, taking into account that their gas storage properties and potential as a recoverable resource. However, several factors governing whether a particular shale will become a shale-gas resource or not, include: (1) organic matter abundance, type and thermal maturity; (2) porosity-permeability relationships and pore size distribution; (3) brittleness and its relationship to mineralogy and rock fabric (Josh et al., 2012). Gas storage in shales may occur in one or more of three forms: (1) free gas in pores and fractures, (2) adsorbed gas in organic matter and on inorganic minerals, and (3) dissolved gas in oil and water (Curtis, 2002; Zhang et al., 2012). Gas is particularly difficult to extract because it is adsorbed on the shale mineral grains and trapped in isolated pores and fractures (e.g., Lee et al., 2011). However, storage and migration of hydrocarbon molecules through shales is complex, slow and not fully understood, owing to the small pore size, low permeability and often isolated pores, and, therefore, it is for this reason that almost all shales require artificial fracturing to obtain commercial flow rates (Slatt and O'Brien, 2011). Taking into account that the conventional techniques are not applicable to unconventional reservoirs due to the complex properties of rocks in shale-gas systems, these low permeability rocks are very challenging to characterize due to their complex nano-metric scale pores and microstructure. Today, it is widely accepted that the presence of organic nanopores within most worldwide shale plays (e.g., Slatt and O'Brien, 2011; Loucks et al., 2012; Curtis et al., 2012a, 2012b; Chalmers et al., 2012), which is likely to be involved in hydrocarbon retention processes in source rocks (e.g., Romero-Sarmiento et al., 2013, 2014). The identification of porosity and pore size distribution in shale-gas has become a high research priority as they are key parameters for the commercial evaluation of a potential shale (Ross and Bustin, 2009; Loucks et al., 2009). Organic porosity is mainly important in the gas generation window, thus limiting their importance mainly to storage of gas. Colombia is the third country in South America with the greatest potential for shale-gas, with 7 high prospectively basins, with the Catatumbo, Middle Magdalena Valley and Eastern Cordillera basins as the most important. According to the National Hydrocarbon Agency

\footnotetext{
*Corresponding author:

Carlos A. Rios, carios@uis.edu.co

Received: June 9, 2015

Accepted: February 6, 2016
}

(ANH), several shale plays have developed in Colombia, including the Cretaceous La Luna Formation in the Middle Magdalena Valley Basin (MMVB), which has been studied as a source rock for many years and has been studied by several researchers (e.g., Morales et al., 1958; Schamel, 1991; Montgomery, 1992; Ramón et al., 1997; Ramon and Dzou, 1999; Rangel et al., 2000a, 2000b). Based on the increasing interest to looking at Latin America's shale potential, Colombia's shale plays could offer very attractive opportunities. La Luna Shale, a well-known major source rock in the MMVB, is emerging as one of the major gas plays of the region, and is among the top worldwide shale gas systems. The aim of this study is to evaluate several approaches for characterizing outcrop samples from the Galembo Member of the Cretaceous La Luna Formation in the MMVB using different analytical techniques to identify pore characteristics that would classify the shales as a potential resource for unconventional gas, taking into account the features that would influence its shale-gas potential and provide a better framework for future evaluation.

\section{Geological setting}

The MMVB is a roughly north-south oriented intermontane basin that separates the Central and Eastern Cordilleras of Colombia (Figure 1), which constitutes a poly-historic basin developed through different stages closely related with the tectonic events of the northwest corner of South America (Kingston, et al., 1983). It is one of the most prolific petroleum basins in Colombia, which has produced most of the oil and gas in Colombia with over 40 discovered conventional oil fields, sourced out of Tertiary sandstone reservoirs (Rodriguez, 2013). Several papers about source rocks in the MMVB have been published (e.g., Zumberge, 1984; Schamel, 1991; Reyes, 1996; Ramon and Dzou, 1999; Rangel, et al., 2000a; 2000b; Aguilera, et al., 2009; Torres et al., 2015). The organic-rich Cretaceous La Luna Formation has traditionally been recognized as the main hydrocarbon source rock in the MMVB (e.g., Zumberge, 1984; Rangel, et al., 1996) and can be considered as a selfcontained source and reservoir system and thus constitutes an unconventional shale play (e.g., Jensen et al., 2013). It consists of calcareous black shales and limestones, with high foraminifera content and limestone concretions, and, based on the facial analyses, its depositional environment is believed to be shallow marine, middle to outer shelf, in a transgressing sea (Torres, 2013). Based on the integration of biomarker ratios, lithofacies and relative hydrocarbon potential, Torres, et al. (2015), suggest that the La Luna Formation was deposited under dysoxic/anoxic conditions and episodic periods of photic zone anoxia during major transgressive-regressive cycles in a restricted middle shelf to upper slope; these sea-level changes affected the redox conditions and the extent of anoxia. Previous workers (e.g., Garner, 1926; Hedberg and Sass, 1937; Hubach, 1957; Morales, 1958; Rangel, et al., 2000a, 2000b) have divided 


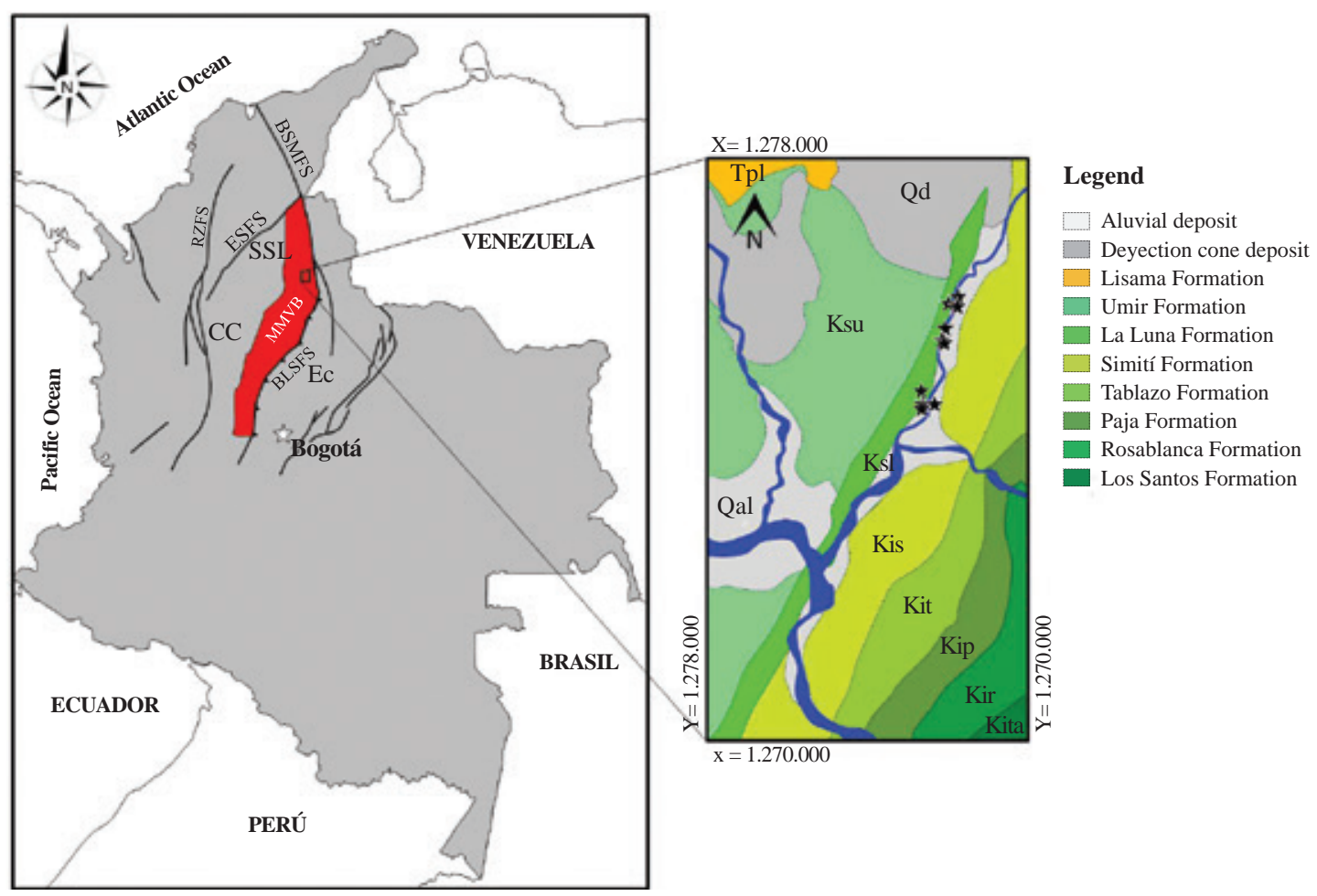

Figure 1. Left, location of the MMVB (red polygon) in Colombia. Figure notations: the Central Cordillera (CC); the Eastern Cordillera (EC); the Bituima and La Salina fault system (BLSFS); the Espiritu Santo fault system (ESFS); the Serranía de San Lucas (SSL); the Bucaramanga-Santa Marta fault system (BSMF) (adapted and modified from ANH, 2008). Right, generalized geological map adapted and modified after Ward, et al. (1969), with sampling localities indicated by black stars.

it into three members (Salada, Pujamana and Galembo) from base to top. Zumberge (1984) determined the thickness of the La Luna Formation between 150 and $600 \mathrm{~m}$, describing it from the litohological point of view as cosisting of calcareous black to dark grey shales, interbedded with mudstones and thin layers of chert with abundant presence of planktonic calceareous foraminifera and other pelagic organisms. The Salada Member of Lower Turonian age (Morales, et al., 1958) overlies the Aptian-Cenomanian Simiti Formation and its thickness ranges from 50 to $100 \mathrm{~m}$. The lower part of the Salada Member consists of greenishgray fine-grained limestones with observed laminae filled with bitumen intercalated with poorly laminated wackestones and calcareous black shales. The wackestones containing mainly planktonic foraminifera with some pyrite traces. The upper part of the Salada Member is composed of muddy laminated dark gray and thin bedded foraminiferal wackestones and calcareous shales with spherical (up to 50 $\mathrm{cm}$ in diameter) to oblate (up to $3 \mathrm{~m}$ in diameter) calcareous concretions, locally displaying a pyrite crust. However, most of the concretions are pyrite-rich. Calcite crystals are cemented and microfractures are filled with bitumen. Foraminifera and fecal pellets are usually oriented parallel to the bedding planes. According to Torres, et al. (2015), these rocks range from clay-rich to diluted carbonate intervals. The Pujamana Member of Upper Turonian to Lower
Coniacian age (Morales, et al., 1958) is mainly composed of black to grey calcareous shales, with intercalations of sandstones in the bottom of this. Its thickness ranges from 50 to $225 \mathrm{~m}$ (Allen, et al., 1993). According Ballesteros and Parra (2012), it represents a transition interval, which is characterized by the intercalation of laminated dark grey phosphatic and calcerous shales with foraminifera and thin layers of limestones, although the upper part consists of a monotonous sequence of laminated shales and calcareous mudstones. Locally, it shows pyrite-rich calcareous nodules (up to $60 \mathrm{~cm}$ in diameter). Torres, et al. (2015) describe these rocks as composed of intercalations of claystone, siliceos mudstone, chert, phospahe and thin bentonite (probably due to wethering of volcanic ashes) layers with abundant foraminifera, muddy laminated wackstones and calcareous dark grey shales at the top and phosphate layers at the bottom. Some of these layers can be filled with hydrocarbons. The Galembo Member of Upper Coniacian and probably Santonian age (Morales, et al., 1958) is discordantly overlied by the Umir Formation. It consists of compacted black laminated calcareous mudstones and intercalated with dark packestones and phosphatic layers, the last of them with abundant rests of fish bones and teeth, and large calcareous cartwheel concretions of up to $8 \mathrm{~m}$ in diameter with ammonites in their centres (at the top), black shales with siliceous cherts, laminated claystones 
and abundant calcareous nodules (at the middle part), and intercalations of micritic limestones and dark cherts (at the bottom). The thickness of the Galembo Member can range from 180 to $350 \mathrm{~m}$ (Morales, et al., 1958). The lower part of the Galembo Member consists of phosphatic packstones and wackstones (e.g., Ramón and Dzou, 1999; Rangel, et al., 2000a, 2000b; Bernal, 2009). Royero y Clavijo (2001), based on the occurrence of remains of fish, pellets and apatite, suggest that the La Luna Formation was deposited in a shallow marine environment, close to the outer edge of the platform. Several stratigraphic sections of the La Luna Formation in the MMVB have been studied in the La Sorda, La Azufrada, Agua Blanca and Agua Buena streams, the Tablazo sector and the Galembo Hill (e.g., Rangel, et al., 2000a, 2000b; Bernal, 2009; Ballesteros and Parra, 2012; Casadiego, 2014; Torres, et al., 2015), the last of them being the closest to the study area. Fractures are filled with calcite. Calcareous fossil shells characterize the limestones as micritic packestones. Based on biomarker analysis and reservoir characterization, Torres (2013) identified as good candidates for an unconventional shale gas plays the Salada and Galembo members of the La Luna Formation, with the transitional Pujamana Member probably representing a lithological barrier. Recently, the Colombian Government has considered encouraging the exploration for unconventional reservoirs in the MMVB, focusing on the study of several core and outcrop samples, which not only promises potential of shale-gas in this region but also indicates that the La Luna Formation emerges as a shalegas play in South America.

\section{Materials and methods}

The investigated samples come from outcrops of the Galembo Member in the MMVB. Thin sections were prepared for petrographic analyses from offcuts of the rock samples with the plane of the section normal to the macroscopic lamination. All samples were impregnated with epoxic resin and stained for carbonates and feldspars and also to recognize the porosity. Petrographic analysis was performed using a trinocular Nikon (Labophot2-POL) transmitted light microscope equipped with an Olympus DP71 camera for image acquisition. Mineral abbreviations are after Kretz (1980). More detailed analyses followed by means of environmental scanning electron microscopy (ESEM) using a FEI QUANTA FEG-ESEM 650 instrument, under the following analytical conditions: magnification $=800-60000 \mathrm{x}, \mathrm{WD}=5.6-14.0 \mathrm{~mm}, \mathrm{HV}=10.0-20.0 \mathrm{kV}$, signal $=\mathrm{ETD} / \mathrm{Z}$ CONT, detector $=\mathrm{SE} / \mathrm{BSED}$. Operational mode was mainly using secondary electrons (SE), although back scattered electrons (BSE), were also useful where contrasts in grey level in the images correspond to contrasts in atomic number and therefore chemical composition of the analyzed area. Particular areas of interest were analyzed to retrieve the chemical composition of the region via energy dispersive X-ray spectroscopy (EDS). EDS Detector EDAX
APOLO X with resolution of $126.1 \mathrm{eV}$ (in. $\mathrm{Mn} \mathrm{K} \alpha$ ). We started examining broken surfaces of sample chips. The thin section was carbon coated before analysis in order to avoid electrical charging. A selected sample was used to apply the FEI's QEMSCAN technology and iDiscover ${ }^{\mathrm{TM}}$ off-line image analysis software. The software package iDiscover consists of four software modules: Datastore Explorer (data management module), iMeasure (measurement module, SEM and EDS control), iExplorer (data processing and classification tools, mineral database management, reports), and SIP editor (phase identification protocol). Automated mineral analyses performed using the System QEMSCAN 650 FEG of the FEI's Center of Excellence for Natural Resources in Brisbane, Australia. A mineral list created to capture all the mineral phases in the sample. All data are reported in volume $\%$ ( $\%$ by weight $)$ per sample. The method of analysis used was Field Image with a resolution of $2 \times 2$ or $10 \times 10 \mu \mathrm{m}$. However, some higher resolution measurements conducted to highlight some textural characteristics and compare the resolution vs. analysis time. Post-measurement processing of the frames performed to create mosaic images using iDiscover, which were used to extract quantitative mineral and petrological data, such as modal proportions (in volume \%) and matrix density. Figure $1 \mathrm{~S}$, http://www. raccefyn.co/index.php/raccefyn/article/downloadSuppFile/ $243 / 1257$, shows the main mineral list used for mineral maps and quantification for the analyzed mudstone sample by QEMSCAN through data processing and reporting. Most rock-forming minerals were identified. For each pixel size a total acquired X-ray data points of 6.285 .575 for $10 \mu \mathrm{m}$ and 2.342.991 for $2 \mu \mathrm{m}$ were obtained to derivate mineralogical data. Ar-ion-milling was performed in a Fischione 1050 mill of Fishione Instruments for high resolution analysis using a FEI's Helios NanoLab ${ }^{\mathrm{TM}} 650$ DualBeam $^{\mathrm{TM}}$. All of the images were collected using backscattered electrons (BSE).

\section{Results}

\section{Field occurrence}

A generalized stratigraphic column of the Galembo Member of the La Luna Formation as part of the Cretaceous sequence outcropping at the MMVB is shown in Figure 2S, http://www. raccefyn.co/index.php/raccefyn/article/downloadSuppFile/ 243/1258. The Galembo Member is underlied by the Calizas del Salto and Simití formations and overlied by the Umir Formation. It is characterized by several lithofacies defined from descriptions of outcrops, which include nonlaminated to slightly laminated foraminifera wackestones, highly fossiliferous moderate- to well-laminated organic-rich mudstones, claystones with fossiliferous carbonate concretions with pyrite, nonlaminated siliceous and fossiliferous claystones, and volcanic ash falls. The analyzed samples show that the Galembo Member are composed dominantly of nonlaminated and slightly laminated foraminifera wackestones, highly fossiliferous moderate- to well-laminated organicrich mudstones (sometimes with fossiliferous carbonate 
concretions with pyrite), and nonlaminated siliceous and fossiliferous claystones, with interlayered thin layers of volcanic ash falls. Field occurrence of the Galembo Member sedimentary rocks is summarized in Figure 3S, http://www. raccefyn.co/index.php/raccefyn/article/downloadSuppFile/ $243 / 1259$

\section{Petrography}

The different grain sizes found in the Galembo Member mudstones correspond to carbonate and siliceous bioclasts, grains of quartz and intraclasts. Figure 4S, http://www. raccefyn.co/index.php/raccefyn/article/downloadSuppFile/ 243/1260, illustrates several microstructural and textural features of the Galembo Member mudstones, which are characterized by sample heterogeneity and black organic matter layers aligned to give the rock a strong anisotropy. Planktonic foraminiferal species are very common and abundant (25-45\%) in organic matter rich-matrix, containing not only abundant microfossils but also non-segmented translucid filaments, which consist of elongated and thin structures that were released from non-determined skeletal alochemical (Figure 4Sa). Figure 4Sb shows a bivalve mold displaying several types of internal layers. An example of alternating organic matter rich- and foraminifera-rich layers is illustrated in Figure 4Sc. Note calcite vein filled with organic matter, which cuts across the rock lamination. Numerous veinlets of calcite cutting across the rock lamination are shown in Figure 4Sd. Bivalve shells are usually replaced by coarse neomorphic calcite (Figure 4Se). Calcite has pseudomorphed the original two layer structure of the shell. Figure 4Sf shows a druzy calcite filling a bivalve cast.

Figure 5S, http://www.raccefyn.co/index.php/raccefyn/article/ downloadSuppFile/243/1261, shows microstructural and textural features of a typical mudstone of the Galembo Member. Figures $5 \mathrm{Sa}-5 \mathrm{Sb}$ are photomicrographs that ilustrate numerous planktonic foraminifera that define a discontinue lamination; note the occurrence of a plurilocular specimen, which is characterized by several chambers as well as the wall and septos. In general, the disposition of the chambers is spherical, although it sometimes is longitudinal to an axis. The secondary electron (SE) image in Figure 5Sc reveals the pattern of distribution of planktonic foraminifera developing a discontinue lamination. The secondary electron (SE) images in Figure 5Sd show the occurrenc of several examples of plurilocular Globigerina bulloides with up to 5 chambers.

\section{QEMSCAN mineral mapping}

The imaging work conducted using a standard polished section a selected mudstone sample of the Galembo Member. SEM-based automated mineralogy analysis includes the use of both BSE and X-rays signals, in conjunction with advanced image and pattern recognition analysis to successfully provide quantitative mineralogical data. Figures $2 \mathrm{a}$ and $2 \mathrm{~b}$ shows a QEMSCAN backscatter image and a mineral map, respectively, of the mudstone sample $(10 \mu \mathrm{m}$ pixel spacing), which reveal the QEMSCAN-derivated host rock mineralogy, highlighting the main features of the analyzed sample. Note the pattern of distribution of fractures following the lamination structure of the rock and also the distribution of the rock-forming minerals.

The mineral map in the left part of Figure 6S, http://www. raccefyn.co/index.php/raccefyn/article/downloadSuppFile/ 243/1262, corresponds to a selected area in Figure $2 \mathrm{~b}$ and shows the laminated fabric of the rock, where clay mineral (illite in green color) flakes display parallel alignement. Quartz (pink) and plagioclase (turquoise) occur in form of elongated grains. The larger particles within the microstructure of the La Luna Formation are planktonic foraminiferal species (Globiginera) as well as detrital quartz and plagiocalse, whereas the fine-grained matrix is mainly composed of clay minerals (mainly illite and kaolinite, with minor chlorite) and calcite. Calcite (light purple) is also elongated although developing a lenticular character. Kaolinite (moderate brown) is observed as a replacement of foraminifera. The quantification of modal phase abundances (modal mineralogy) presented in the legend (right part of Figure 6S) represents a quantum leap in the currently employed mineralogical analysis of the analyzed mudstone sample. The lower part of Figure $6 \mathrm{~S}$
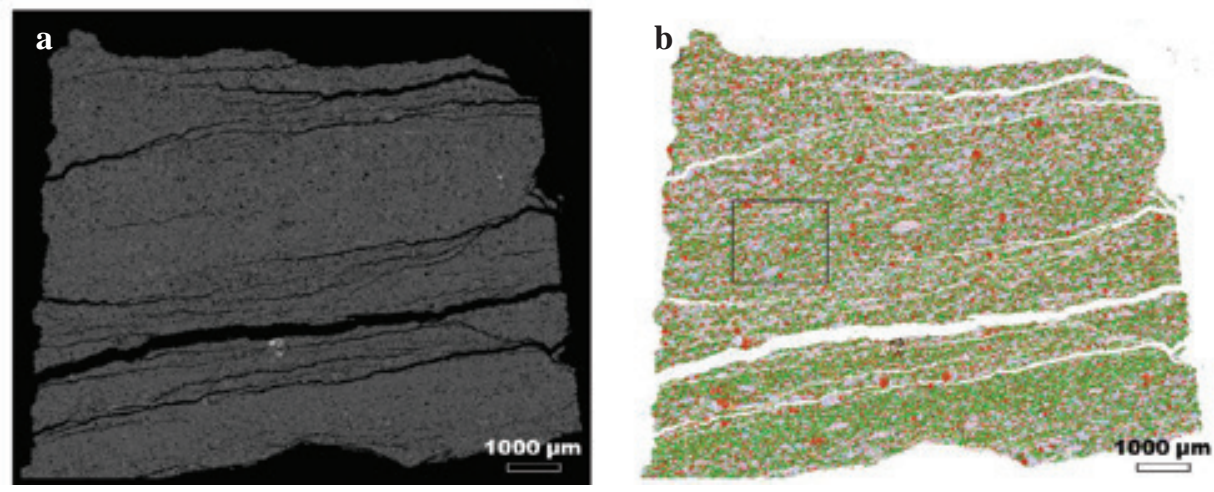

Figure 2. QEMSCAN (a) backscatter image and (b) mineral map of a mudstone sample of the Galembo Member (10 $\mu \mathrm{m}$ pixel spacing). 
show the results of the modal analysis (in $\mathrm{wt} \%$ ), which reveals that the sample contains major kaolinite $(24.34$ $\mathrm{wt} \%)$, illite $(22.23 \mathrm{wt} \%)$, calcite $(22.18 \mathrm{wt} \%)$, quartz $(19.25$ $\mathrm{wt} \%)$, and minor plagioclase (4.59 wt $\%)$, apatite $(2.22 \mathrm{wt} \%)$ and biotite $(1.04 \mathrm{wt} \%)$. Trace amounts $(<1 \%)$ of siderite, smectite, muscovite, chlorite, epidote-group minerals, phosphates, rutile, sulfates and pyrite are also present. There is a portion of the scan that is not classified (referred to as Other). It does not mean that the elemental composition of these points is unknown, simply that there was no mineral definition in the Species Identification Protocol (SIP) that was consistent with the measured spectra.

\section{FEG-SEM analysis}

FEG-SEM analysis reveals that analyzed samples show an important porosity, with some differences. Porosity may be expressed in several types, which are described in detail below. Figure 3 illustrates several interesting microstructural features of the Galembo Member of the La Luna Formation, particularly in fractured surfaces, such as bedding planes and crystal habits. According to Loucks, et al. (2012), the pores within gas mudstones can be grouped into three types: (1) mineral matrix pores between or within mineral particles; (2) pores within organic matter and (3) fracture pores that are not controlled by individual particles. However, we adopt the classification proposed by Slatt and O'Brien (2011), which includes interparticle pores produced by flocculation, organoporosity produced during burial and maturation, intraparticle pores from organisms (e.g., fecal pellets, fossil material), intraparticle pores within mineral grains, microchannels and microfractures, to describe the pore types that are present in the analyzed samples. Figure 3a shows a fractured surface looking parallel to bedding planes that does not reveal the best view of porosity. Clay
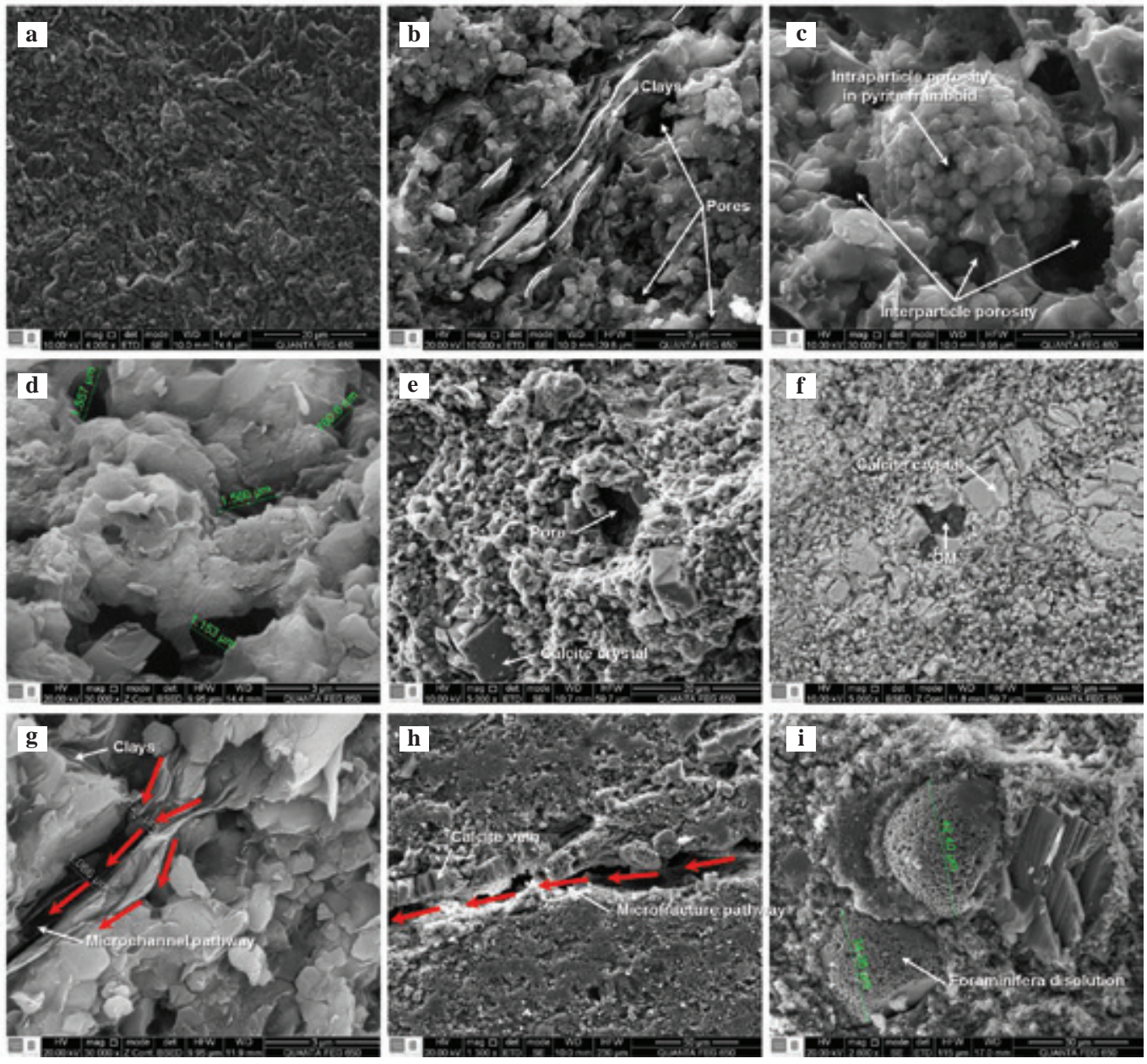

Figure 3. SEM images of fractured surface in the Galembo Member mudstones. (a) A fractured surface looking parallel to bedding planes. (b) A fractured surface looking perpendicular to bedding planes, which are easily visible. (c) Framboidal pyrite nearly invisible using secondary electrons; note the turning of clays around framboidal pyrite and porosity. (d) Fractured surface displaying several pores. (e) Fractured surface showing several crystal of calcite with a rhombohedral. (f) BSE image of atomic number contrast showing an organic matter-rich region. (g) Microchannels as permeability pathways. (h) Microfracture partially filled with calcite. (i) Foraminifera porosity due to carbonate dissolution. 
particles are mainly present in highly fossiliferous moderate to well-laminated claystones rich in organic matter. In general, they form layers of open nano-micrometric flakes (Figures 3b, 9g). However, they also use to develop clay floccules, which can form a "cardhouse" structure of individual edge-face- or edge-edge-oriented flakes similar to what is reported by other authors (e.g., O'Brien and Slatt, 1990; Bennett et al., 1991; Slatt and O’Brien, 2011). According to Slatt and O'Brien (2011). Organoporosity due to burial and thermal maturity of organic matter was first reported by Loucks et al. (2009), and according to Jarvie et al. (2007), these pores are generated during burial and maturation of organic matter. Casadiego (2014) reports the occurrence of organoporosity in nonlaminated to slight laminated foraminifera wackestones in two ways: (1) organic matter with a pendular morphology filling pore spaces between calcite crystals, with pores showing an elongated and angular shape, some of them interconnected; (2) laminar solid organic matter with low content of interconnected microporous space, with isolated pores, which according to Loucks, et al. (2012) can be associated to immature organic matter. The Galembo Member mudstones usually contain framboidal pyrite, which are composed of several small pyrite crystals between which intraparticle pores occur (Figure 3c). Organisms may produce intraparticle porosity by bioturbation of sediments, by generation of fecal pellets, and by the porous nature of their skeletons or shells (Slatt and O'Brien, 2011). These rocks contain abundant planktonic foraminiferal species, and rests of echinoderms spicules, broken gastropods and bivalves and fish bones and teeth. Figure $3 \mathrm{~d}$ shows a fractured surface displaying interparticle pores between mineral grains, some of them interconnected and distributed along bedding planes (Figures 3b, 3d), developing permeability pathways for gas fluid (Figure 3g) as suggested by Slatt, et al. (2012). A fractured surface is also very useful to observe crystals or grains (Figure 3e). Figure 3f illustrates a BSE image of atomic number contrast showing a small organic matterrich region within a calcite vein. They also can show several examples of microchannels, which occur within the mudstone matrix (Figure 3g). These microchannels, if abundant, they could provide significant permeability pathways, in addition to microporosity (Slatt and O'Brien, 2011). They show a sinuous and discontinuous shape and are following the stratification plane. According to Slatt and O'Brien (2011), the microchannels cannot be interpreted as artifacts produced by pressure release when fracturing the sample during handling and preparation, but represent original microchannel openings preserved in the undisturbed shale matrix. Microchannels are of millimeter scale in width, which is wide enough to provide a permeability passage for gas flow. On the other hand, microchannels also occur at the boundary between rigid bioclasts and mudstone matrix. Microfractures (Figure 3h) in mudstones occur at a variety of scales (e.g., Gale and Holder, 2010; Slatt, et al., 2012) and are significant in any fabric investigation of mudstone properties, particularly those related to artificial fracture treatment (Slatt and O'Brien, 2011). In the Galembo Member mudstones, microfractures of may be filled with organic matter or partially open. Nonlaminated to slight laminated foraminifera wackestones shows few microfractures filled with calcite $(<1 \%)$, possibly due to its high carbonate content (80-96\%). The porosity is mainly associated to foraminiferal dissolution (Figure 3i).

However, fractured surfaces of mudstones hide the nature of pores. Ar-ion-milled surfaces can show us pore morphology, taking into account that ion milling removes polishing artifacts and gives us a very low relief surfaces. Figure 7S, http://www.raccefyn.co/index.php/raccefyn/ article/downloadSuppFile/243/1263, Figure 4 and Figure 8S, http://www.raccefyn.co/index.php/raccefyn/article/ downloadSuppFile/243/1264, illustrates examples of ion milled surfaces of the Galembo Member mudstones. The mineral matrix pores are mainly developed between and within calcite crystals, quartz grains, clay minerals and pyrite framboids. The organic matter usually contains pores of several shapes and sizes (micro-meter to nanometer scale), which are sometimes connected by narrow throats. Microfractures can be observed particularly in the boundary between foraminifera and calcite matrix or in the brittle quartz- and calcite-rich matrix. However, they can be attributed to shrinking of clay minerals and/or decompression effect after the retrieval from subsurface (Chalmers et al., 2012). Although FEG-SEM imaging provide a very useful qualitative information on the pore types in mudstones (e.g., Loucks et al., 2009; Slatt and O'Brien, 2011; Slatt, et al., 2012; Curtis et al., 2012a, 2012b; Milliken et al., 2013), the total porosity, which includes fluids associated with mudstones, is usually calculated by the difference between the bulk and grain densities (Chalmers et al., 2012).

We illustrated several examples of a variety of pore types that are present in the La Luna Formation, using the classification proposed by Slatt and O'Brien (2011). The pores observed in the analyzed samples are enough not only to store hydrocarbon molecules but also to promote their flow though pathways. Porosity is associated to flocculation of clays probably with greatest potential, along with microfractures and organoporosity, to provide storage places as well as permeability pathways for migration of hydrocarbons. Torres et al. (2015) report in these rocks clay floccules and interparticle porosity, globigerina shell replacement with calcite and microchannel porosity in these rocks. The porosity obtained by depositional and diagenetic processes are influenced by several factors, such as compaction, cementation and dissolution of minerals. Claystones can show greater compaction and deformation, where it is possible to distinguish the deformation around bioclasts and discontinue laminations of organic matter. Samples with high content of carbonates and phosphates 

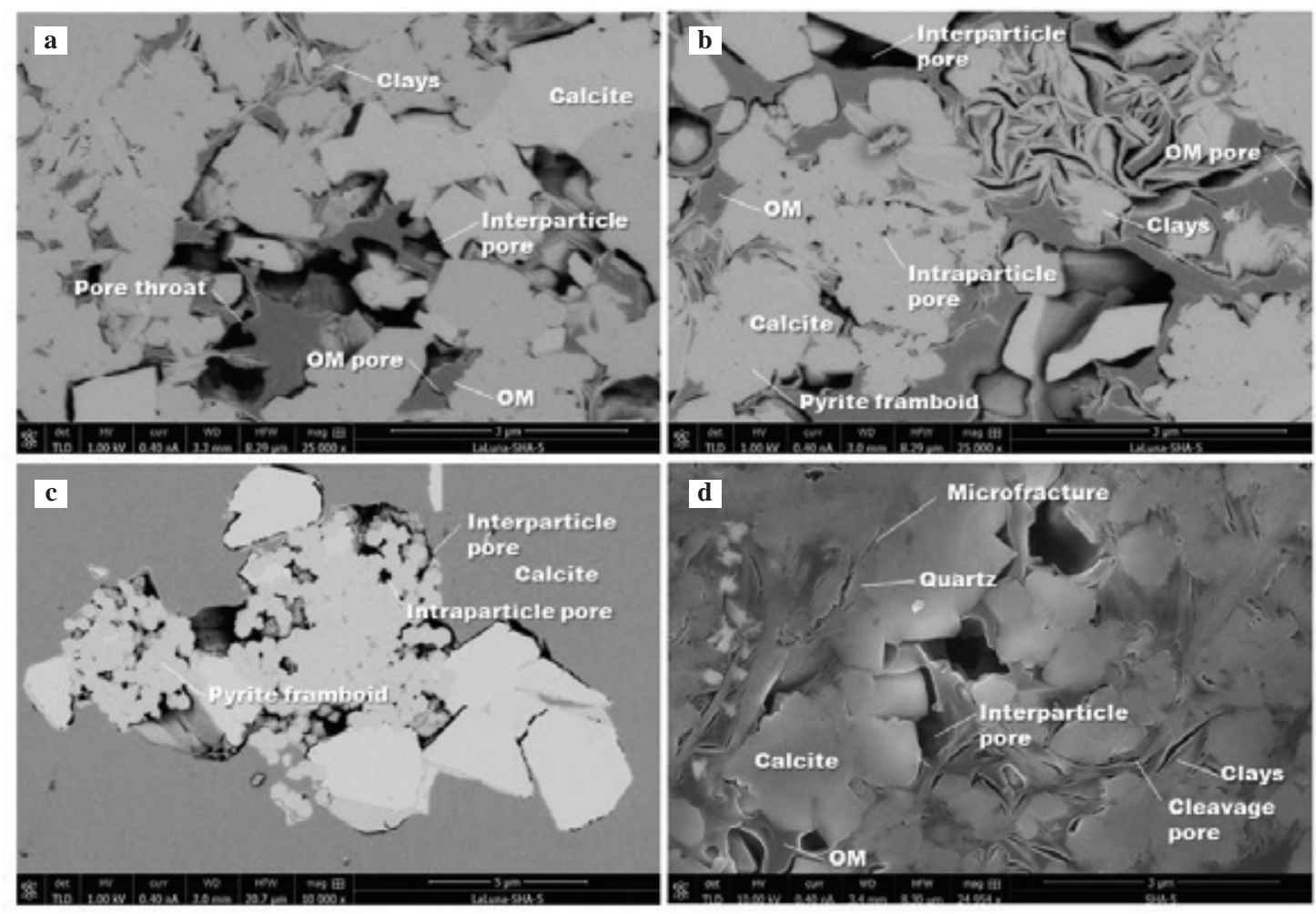

Figure 4. Porosity in ion milled surfaces of the Galembo Member mudstones.

have little compaction and moldic porosity (3\%). Samples with high content of pyrite and quartz do not show dissolution and show very low compaction. Samples with the highest quartz content $(>40 \%)$ present fractures perpendicular to lamination, which are filled with organic matter or carbonates.

\section{Discussion on microstructures and pores}

According to Casadiego (2014), most of the Galembo Member rocks have $T_{\max }$ values ranging from 439 to $448{ }^{\circ} \mathrm{C}$ and Production Index (PI) values ranging from 0.02 to 0.1 , indicating that these rocks are in the oil window, although with a low PI. He also reported high values of $\mathrm{S}_{1}$ and PI, suggesting that the primary oil migration occurred in the upper part of the Galembo Member and coincides with a $\mathrm{T}_{\max }$ indicating a low thermal maturity. Figure $9 \mathrm{~S}$, http://www. raccefyn.co/index.php/raccefyn/article/downloadSuppFile/ 243/1265, shows a Van Krevelan diagram, displaying the relationship between $\mathrm{HI}$ (mg HC/g TOC) vs. OI (mg $\mathrm{CO}_{2} / \mathrm{g}$ TOC), where the plotted data provides a very useful information on kerogen type. All the samples are relatively clay-poor, ranging from 6 to $27 \mathrm{wt} \%$, and no apparent trend between TOC values and the total clay contents was observed. Pyrolysis Rock Eval data indicate that rocks of the Galembo Member contain a kerogen of type III, with foraminifera wackstones and siliceous and fossiliferous claystones showing lower and higher thermal maturity compared with highly fossiliferous claystone rich in organic matter.
At a low maturity phase (during deposition and shallow- to intermediate-burial), interparticle and intraparticle pores developed in the Galembo Member mudstones, whereas at a high maturity phase (during deep-burial and hydrocarbongeneration window), organic-matter pores are highly developed as suggested by Loucks et al. (2012). Organic porosity is mainly important in the gas generation window, thus limiting their importance mainly to storage of gas. Several studies have been performed on the role of the organic porosity (nature and distribution of pores in organic matter) and adsorption mechanisms of the gas storage in these shale and more precisely within the kerogen itself (e.g., Jarvie et al., 2007; Ross and Bustin, 2009; Loucks et al., 2009; Bernard et al., 2011; Slatt and O'Brien, 2011; Curtis et al., 2012a; Chalmers et al., 2012; Loucks et al., 2012). On the other hand, several parameters influence the hydrocarbon retention mechanisms, which include the relative solubility of petroleum compounds in kerogen (e.g., Ritter, 2003), solubility of light hydrocarbons in the gas phase (e.g., Meulbroek et al., 1998) or in the water phase (e.g., Lafargue and Barker, 1988). Furthermore, gas adsorption can occur on mineral surfaces (e.g., Brothers $\boldsymbol{e} t$ al., 1991) as well as in organic matter (e.g., Ritter, 2003). Furthermore, gas adsorption can occur on mineral surfaces (e.g., Brothers et al., 1991) as well as in organic matter (e.g., Ritter and Grover, 2005). Recently, it has been shown that organic matter can develop micro-meter to nanometer scale porosity during its maturity evolution (e.g., 
Vermylen, 2011; Bernard et al., 2011; Curtis et al., 2012a; Chalmers et al., 2012; Loucks et al., 2012). Curtis et al. (2012b) have demonstrated the change in porosity with increasing thermal maturity. According to them, the occurrence of non-uniform porosity in the organic matter suggests that something in addition to thermal maturity (e.g., type of organic matter) is controlling organic pore formation. We have observed in the La Luna Formation shales that not all organic matter regions show the same porosity at specific thermal maturity conditions, which confirms that other factors, such as organic matter type, complicate pore system development, and, therefore, thermal maturity alone is insufficient to predict porosity development in shales. On the other hand, La Luna Formation shales can show oil window samples without porosity in the organic matter (Figure 4 and figures 7S and 8S), which indicates that it is necessary to look for storage areas in the inorganic mineral phases (clays, quartz, calcite and pyrite) in the matrix. The pore morphology resulting from hydrocarbon generation can be mostly circular and elliptical (Yao et al., 2011), which we have not defined in this study, taking into account that the morphology can change under the influence of several factors, in addition to thermal maturity (Jiao et al., 2014). According to them, larger pores tend to have more complex cross-sections due to two reasons: (1) larger pores are commonly the result of a few smaller pores combining, which promotes the development of irregular cross-sections, and (2) larger pores are influenced by stress more easily than small pores, which tend to preserve their original shape. Therefore, taking into account the thermal maturity reached by the La Luna Formation, organic matter pores most likely resulted from the generation of hydrocarbons (Chalmers, $\boldsymbol{e t}$ al., 2012; Loucks, et al., 2012). La Luna Formation presents a good potential for a shale-gas system, taking into account its high content of organic matter. According to geochemical data (e.g., Torres, 2013; Casadiego, 2014), it has reached maturity levels for hydrocarbon generation and has relatively high porosity for oil and/or gas storage. Torres (2013) attributes differences due to dramatic changes in maturity, from an oil window to a deep dry gas window. The evolution of the pore structure of the Galembo Member mudstones can be discussed by differentiating interparticle pores due to flocculation of clay minerals, organoporosity due to burial and thermal maturity of organic matter, intraparticle pores from organisms, intraparticle pores within mineral grains, and microchannels and microfractures, which is very useful to relate the porosity evolution to diagenesis. Interparticle pores usually are aligned along the boundaries of inorganic (quartz grains, calcite crystals and platelets of clay minerals) or organic particles, and dispersed within the mudstone matrix. They commonly have slit- or irregular shaped morphology and are larger than organic-matter pores. Bernard, et al. (2013) consider that they are highly sensitive to burial, with pores displaying an elongated spheroidal shape within immature mudstones, pronounced ellipsoidal shape within mature mudstones, and almost totally closed in overmature shales. The evolution of this type of porosity can be related to compaction and cementation during burial, which cause interparticle pores to collapse (e.g., Milliken and Reed, 2010). Intraparticle pores in immature mudstones are observed within mineral grain boundaries and are generally polyhedral with straight margins and mostly associated with carbonate shells of microfossils, and with increasing maturity, they are progressively filled by diagenetic carbonate cements (Bernard, et al., 2013). According to Bernard, et al. (2013), the number and size of intraparticle pores associated with framboidal pyrite increase with increasing maturity. On the other hand, most of these pores are filled with bitumen in overmature samples, indicating that they were once sufficiently interconnected to allow for bitumen to migrate (Bernard, et al., 2013). We report also the occurrence of organic matter and/or clay minerals in pyrite framboids within the Galembo Member mudstones, which is indicative of anaerobic sulfur diagenesis (Slatt, et al., 2012). On the other hand, this type of pores is also observed within calcite and clay minerals (cleavage pores), which can be related to organic matter thermal degradation by decarboxylation (Bernard, et al., 2013). According to Moore (1997), this process has likely produced organic acids that partially dissolved calcite and clay minerals. Therefore, intraparticle pores are more sensitive to chemical diagenesis than to mechanical diagenesis compared with interparticle pores (Bernard, et al., 2013). Organoporosity is not the most abundant pore type. However, it looks similar to what is reported in several studies from North America (e.g., Slatt and O’Brien, 1990, 2011; Bennett, et al., 1991; Loucks, et al., 2009; Curtis et al., 2012a; Loucks, et al., 2012), which leads the world in production of shalegas. This type of porosity was probably developed during thermal madurity. According to Loucks, et al. (2009), the organoporosity is most likely a result of the exsolution of hydrocarbon gas during the thermal cracking of retained oil. Microfractures are usually related to quartz grains or calcite crystals. It is common to observe organic matter within microfractures filled with calcite. Microfracturing, which is a process resulting from increased fluid pressure, represents a primary mechanism for the circulation of fluids from deeps basins where thick abnormally pressured sedimentary sections are present, which would be enhanced by clay diagenesis since $\mathrm{H}_{2} \mathrm{O}$ supplied from smectite would cause the process to continue for longer periods of time and to extend to greater depths than could be attained if only remnants of the original pore $\mathrm{H}_{2} \mathrm{O}$ were present in the section (Bruce, 1982). On the other hand, diagenetic $\mathrm{H}_{2} \mathrm{O}$ present within microfractures could also act as a vehicle for primary hydrocarbon migration. Low porosity and permeability mudstones, rich in organic matter, with sufficient fractures or a significant fracture systems formed by microfractures and nano-pores/fissures (e.g., Curtis, 2002a; Warlick, 2006) may be an effective natural gas reservoir 
(Sun, et al., 2008). During diagenesis the transformation of smectite to illite occurred in the Galembo Member mudstones, which was accompanied by the expulsion of $\mathrm{H}_{2} \mathrm{O}$ molecules from smectite to the pore system. $\mathrm{H}_{2} \mathrm{O}$ may migrate out of the shale early or may be totally or partly trapped and released slowly through time (Bruce, 1982). The illitization of smectite is active in deeply buried sedimentary sequences (e.g., Bjorlykke, 2013). However, shallow, early growth of diagenetic phases has also been reported (e.g., Lash and Blood, 2004), and, therefore, their precipitation is considered an important factor in textural alteration and associated porosity and permeability reduction. According to Torres (2013), the deposition of organic carbon rich intervals of the La Luna Formation in the MMVB was governed by the development of paleobathymetric barriers, which enhanced the development of anoxia in the Cretaceous sea by causing poor circulation and limited ventilation, and also by high evaporation and low precipitation rates (high salinity bottom water) and high levels of marine algal productivity (high organic matter flux). From microstructural observation, it can be inferred that the post-depositional and diagenetic history of the La Luna Formation included episodes of calcite cementation, pyritization of organic matter and illitization of smectite. Calcite dissolution is also visible in the partially dissolved shells of foraminifera as well as precipitation of clay (kaolinite) in these shells. Quartz cementation was also part of the diagenetic history and may attribute to the transformation of smectite to illite, which is known to release not only $\mathrm{H}_{2} \mathrm{O}$ but also $\mathrm{SiO}_{2}$ under particular physicochemical conditions (Boles and Franks, 1979). Flocculation at the bottom of the sea usually produces a random particle distribution of clay minerals, which suggests that the strong particle alignment observed in the Galembo Member mudstones is the result of a mechanical rotation of the clay minerals during burial due to increasing overburden stress and possibly chemical transformation of the clay minerals. Previous studies suggested that to achieve a significant illite preferred orientation, reactions of diagenetic clays, such as the illitization of smectite, may be critical and produce abrupt increases in fabric intensity with depth (e.g., Ho, et al., 1999; Day-Stirrat, et al., 2008). The microstructure of the Galembo Member mudstones, itself a result of the original deposition environment and subsequent diagenesis, exerts a primary control on their physical properties; there is a good correlation between the degree of alignment of illite and the elastic anisotropy of the rock, as well as between the mineralogy and the strength and stiffness of the rock (Delle Piane, et al., 2015), which is summarized in Figure 10S, http://www.raccefyn.co/index.php/raccefyn/ article/downloadSuppFile/243/1266.

Gas reservoirs, such as the Galembo Member mudstones, are characterized of an organic-rich deposition with extremely low matrix permeability and clusters of mineral-filled "natural" microfractures (Guo, et al., 2013). According to Loucks, et al. (2009), shale-gas strata are composed of micro and nanopores, with the majority being nanopores. According to Guo, et al. (2013), these facts emphasize the importance of studying how gas flows in nanopores, which will be critical for shale-gas simulation and effective commercial production. Figure 5 illustrates an example on how gas distribution in the Galembo Member mudstones from macro-meter to micro-meter scale is. According to Chen, et al. (2011), the sorption capacity of a shale-gas reservoir increases with depth. On the other hand, previous works (e.g., Ross and Bustin, 2007; Chen, et al., 2011) reveal that the organic matter was in part responsible for gas adsorption. There is no doubt that pore networks in the Galembo Member mudstones show an evolution during diagenesis and catagenesis. Recent studies (e.g., Loucks, et al., 2009, 2012) reveal that organic porosity is visible at high thermal maturity level, which suggests that the organic porosity formation is probably not affected by compaction (Romero-Sarmiento, et al., 2013). We consider that the porosity increases with the burial depth, which can affect the rocks in several aspects, taking into account changes in the pressure and temperature conditions and maturity during diagenesis. Romero-Sarmiento, et al. (2013) suppose that most of the overburden sediment pressure is grain supported (or compensated by the overpressures present in the formation) at the onset of the kerogen maturation, preserving the organic material from compression. In addition, there is probably, parallel to the kerogen, diagenetic evolution of the rock matrix which leads to cementation (quartz or carbonate formation) and then increases the mechanical resistance of the source rock to compaction (Mondol, et al., 2007). At the beginning of the diagenesis, the La Luna Formation shales did show very low porosity, but with increasing depth and progression of diagenetic process, which include compaction, cementation and dissolution of minerals, porosity increased particularly associated to organic matter and gas can be easily injected in the pores. On the other hand, microfractures progressive develop along the contact between foraminifera and clays by difference in mechanical strength. Modica and Lapierre (2012) suggested that pores in organic matter do not compact because of their nono-metric scale. Therefore, RomeroSarmiento, et al. (2013) assumed that organic matter porosity is mainly controlled by mass balances of the kerogen transformation. We observe clear differences due to dramatic changes in maturity, from an oil window to a deep dry gas window. In our case, gas retention can be associated to organic matter content, however, it is suggested to perform a detailed study to estimate the distribution.

Numerous studies have been developed on adsorption processes (e.g., Lu, et al., 1995; Montgomery, et al., 2005; Weniger, et al., 2010). According to Romero-Sarmiento, et al. (2013), $\mathrm{CH}_{4}$ adsorption takes place because of the surface reactivity of the carbon present in the solid organic matter 


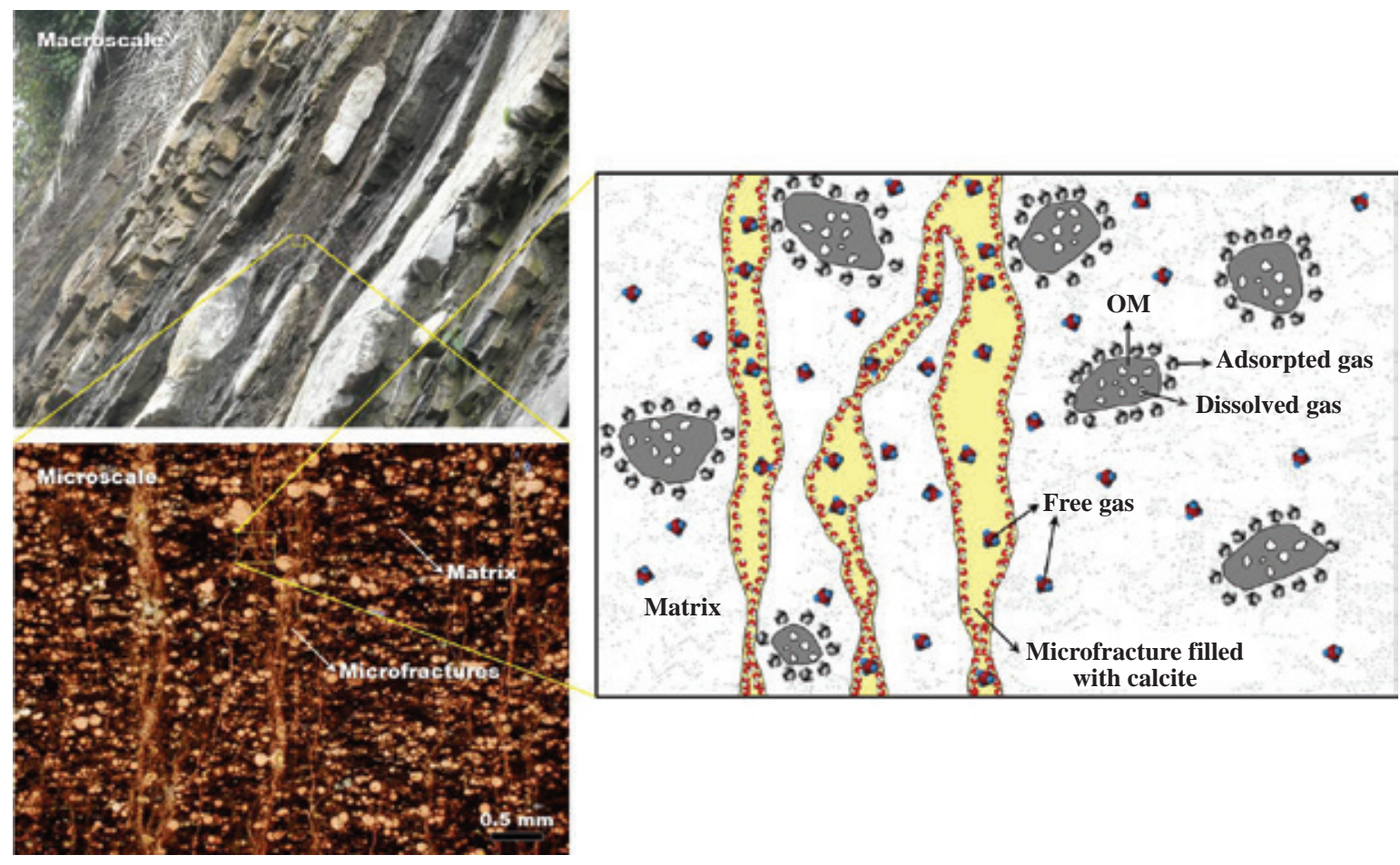

Figure 5. Conceptual model of gas distribution in the Galembo Member mudstones from macro-meter to micro-meter scale (adapted and modified from Guo, et al., 2013).

within source rocks, which is therefore responsible for gas retention. However, it is necessary to take into account the effects of overpressure as well as the sorption competition between different gases, such as $\mathrm{CH}_{4}$, ethane, propane and $\mathrm{CO}_{2}$, and their impacts on $\mathrm{CH}_{4}$ retention capacities in source rocks. Several authors (e.g., Zumberge, et al., 2012) proposed that the gases produced from shales are derived from both primary kerogen cracking and secondary cracking of non-migrated hydrocarbons. However, a good understanding of both generation and retention mechanisms is absolutely necessary to estimate the amount of adsorbed and free gas within these complex source-rock systems (Romero-Sarmiento, et al., 2013). Regarding expulsion efficiency and its effect on adsorption, it is probable that gas is first adsorbed on organics considering their closed reactive surface. Then, the remaining free gas (exceeding the adsorption capacity of the organic matter) only can move out of the source rock. However, we consider that in the pore system (including microfractures) not only free gas exist but also $\mathrm{H}_{2} \mathrm{O}$, which should be the transport agent for gas $\left(\mathrm{CH}_{4}\right)$ flow as shown in Figure 6. In the matrix free gas and adsorption gas co-exist, however, as suggested above, the role of $\mathrm{H}_{2} \mathrm{O}$ during fluid flow should be also considered. Fluid flow in mudstones of a shale-gas system consists of two-phase (gas and $\mathrm{H}_{2} \mathrm{O}$ ) mechanism, which includes transport in extremely low permeability and high porosity media. The presence of hydrocarbons at different maturity levels within the pore system is also characteristic. Therefore, consideration of hydrocarbon content and its maturation history should be very helpful in accurately modeling of fluid flow in mudstones.

\section{Conclusions}

In this work, we illustrate several examples of the pore types that are present in the Galembo Member of the La Luna Formation sedimentary rocks at the MMVB. Porosity is associated to interparticle and intraparticle (framboidal pyrite and cleavage pores within clay minerals) pores, organopores, microchannels and microfractures. Microchannels provide significant permeability pathways for gas flow. However, porosity due to connectivity of pores has perhaps the greatest potential, along with microfractures, to provide not only storage places of hydrocarbon molecules but also permeability pathways for their migration. The integration of several methods, including stereomicroscopy of hand-sample specimens, petrography of thin sections, SEM/EDS analysis, QEMSCAN mineral mapping, and FEG SEM analysis, was very useful for the characterization of pore types in the analyzed samples. The mineralogy of the Galembo Member mudstones has important effects on the storage of gas. We have identified at the bottom of the studied stratigraphic sequence, siliceous and fossiliferous claystones with higher quartz content of more than $65 \%$, which represent appropriate geologic horizon for the exploration and development of shale-gas systems. The porosity increases with the burial depth. According to Chen, 


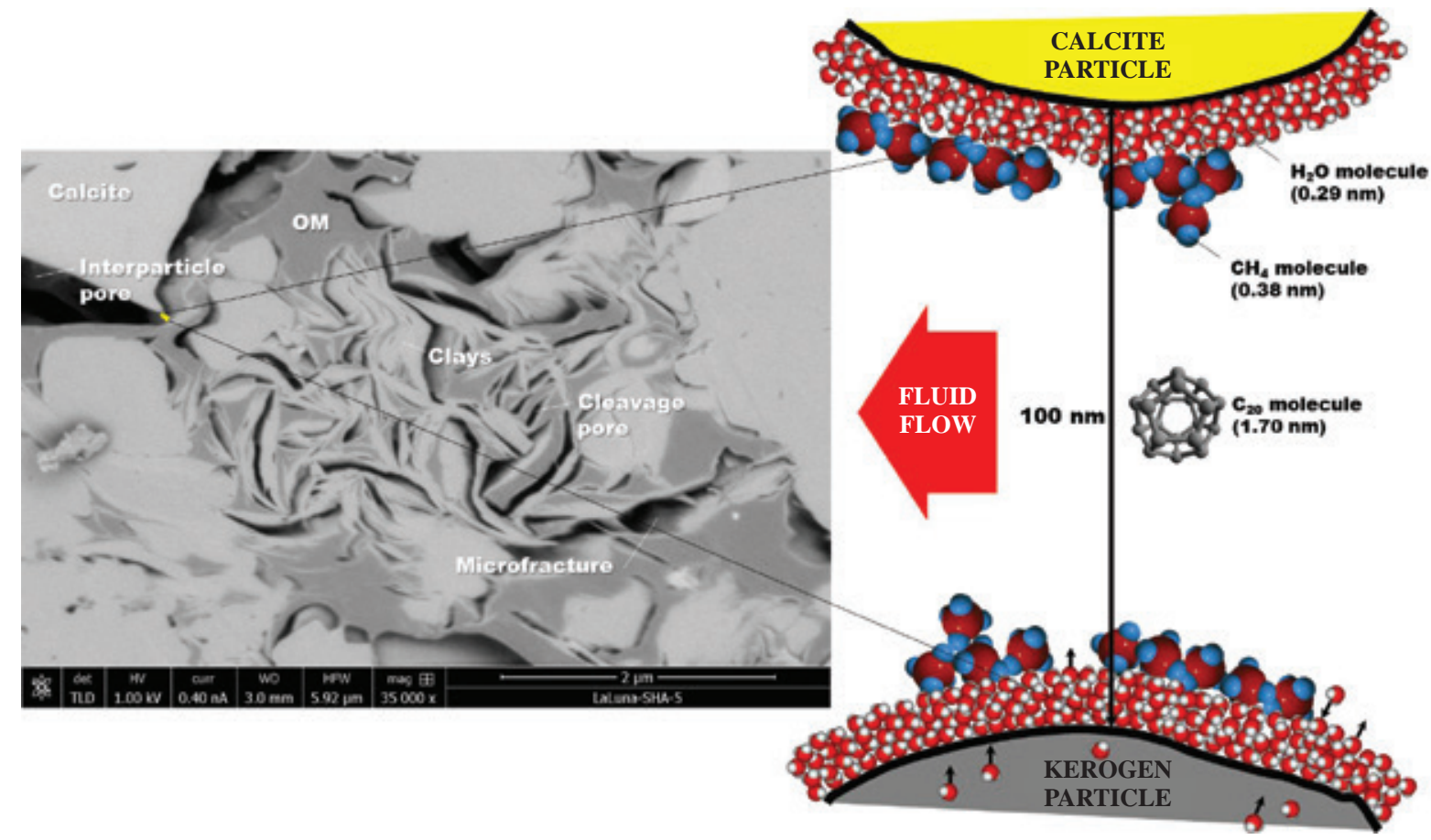

Figure 6. Conceptual model of flow mechanism along the pore system of the Galembo Member mudstones (adapted and modified from Williams, 2012).

et al. (2011), the porosity has a significant positive correlation with the brittle mineral content and a significant negative correlation with the clay mineral content. Casadiego (2014) reports a similar trend in the study area. We have followed a workflow, integrating data, to carry out a characterization of a shale gas (unconventional) reservoir, such as the Galembo Member mudstones of the La Luna Formation, which can be applied in several sectors to produce an assessment of the potential in an area of interest that can reveal its characteristic vertical and lateral heterogeneity. However, it should be interesting to perform a more accurate and detailed study of this geological unit in order to provide evidences on its postdepositional diagenetic history and to develop a true integral evaluation of mudstones in shale-gas systems.

\section{Información suplementaria}

Figure 1S. Main mineral list used for mineral maps and quantification.

Figure 2S. Left, generalized stratigraphic column of the Cretaceous sequence at the MMVB (modified after Reyes, et al., 2000; Barrero, et al., 2007). Right, generalized stratigraphic column of the Upper Coniacian and probably Santonian Galembo Member of the La Luna Formation after Casadiego (2014).

Figure 3S. Photographs at outcrop scale of the occurrence of sedimentary rocks of the Galembo Member. (a) Welllaminated organic-rich claystone with carbonate concretions. (b) Carbonate concretions in organic-rich claystones; several broken concretions reveal the presence of rare fish bones and teeth (c) and common ammonites (d). (e) A typical outcrop of phosphoric rock.

Figure 4S. Microstructural and textural features of the Galembo Member mudstones, highligthing their sample heterogeneity and how black organic matter layers are aligned to give the rock a strong anisotropy.
Figure 5S. Microstructural and textural features of a typical mudstone of the Galembo Member, which contains numerous planktonic foraminifera.

Figure 6S. Left, QEMSCAN mineral map (0.7 $\mu$ m pixel spacing) of the selected area in Figure 2b. Right, legend indicating the recognized mineral phases. Below, the calculated modal abundances in $\mathrm{wt} \%$.

Figure 7S. Porosity in ion milled surfaces of the Galembo Member mudstones.

Figure 8S. Organoporosity in nonlaminated to slight laminated foraminifera wackestones of the Galembo Member.

Figure 9S. Relationship between HI (mg HC/g TOC) vs. OI (mg $\mathrm{CO}_{2} / \mathrm{g}$ TOC) of the Galembo Member mudstones (adapted and modified after Van Krevelan, 1950).

Figure 10S. Conceptual model summarizing the post depositional evolution of the Galembo Member mudstones (adapted and modified from Delle Piane, et al., 2015). 


\section{Acknowledgments}

This work formed part of the MSc Thesis carried out by E. Casadiego at the School of Geology of the Universidad Industrial de Santander. The authors thank to the Universidad Industrial de Santander for allowing us the use of its research facilities at the Guatiguará Technological Park: the Laboratory of Transmitted Light Microscopy of the Research Group in Basic and Applied Geology attached to the School of Geology, and the Laboratory of Microscopy attached to the Vicerrectoría de Investigación y Extensión and their professional staff for assistance with SEM data acquisition and analyses. We are indebted to D. Lattanzi, L. Salazar and P. Jaime from the FEI's Center of Excellence for Natural Resources in Brisbane (Australia) and to M. Curtis, J. Jernigen and Ch. Rai from the FEI-OU Pore Scale Characterization Laboratory of the Mewbourne School of Petroleum and Geological Engineering, University of Oklahoma (USA) for contributing us with the data acquisition by QEMSCAN technology and iDiscover ${ }^{\mathrm{TM}}$ offline image analysis software, and ion milling for FESEM analysis imaging and analysis, respectively. The authors also acknowledge to the anonymous referees for their critical and insightful reading of the manuscript. We are most grateful to the above-named people and institutions for support.

\section{Conflict of interest}

The author declares that he has no conflict of interest.

\section{References}

Allen R.B., Alfonso, C.A., Ressetar, R., Salazar, A., Ballesteros, I., Cardozo, E., Laverde, F., Ramirez, C., Moreno, J.M., Rubiano, J. \& Sarmiento, L. (1993). The Cretaceous stratigraphy of the Western Cordillera Oriental, Colombia. University of South Carolina, Columbia, South Carolina, United States. AAPG Bulletin 02, 77(2).

ANH, 2008. Colombian Sedimentary Basins: Nomenclature, boundaries and petroleum geology, a new proposal, 92p.

Aguilera, R.C., Sotelo, V.A., Burgos, C.A., Arce, C., Gómez, C., Mojica, J., Castillo, H., Jiménez, D. \& Osorno, J. (2009). Organic Geochemistry Atlas of Colombia: An Exploration Tool for Mature and Frontier Basins. Earth Sciences Research Journal 13, Special Edition 1-174.

Ballesteros, C.A. \& Parra, J.A. (2012). Estudio estratigráfico secuencial para la Formación La Luna en el costado oriental de la Cueca del Valle Medio del Magdalena: Una visión exploratoria de hidrocarburos no covencionales. Tesis de Pregrado. Universidad Industrial de Santander.

Barrero, D., Pardo, A., Vargas, C. \& Martínez, J. (2007). Colombian Sedimentary Basins: Nomenclature, Boundaries and Petroleum Geology. ANH and B\&M Exploration Ltda 26-45.

Bennett, R.H., O’Brien, N.R. \& Hulbert, M.H. (1991). Determinants of clay and shale microfabric signatures: processes and mechanisms, in Microstructure of Fine Grained Sediments: From Mud to Shale: Springer-Verlag, New York, p. 5-32.
Bernal, L.A. (2009). Caracterización estratigráfica y petrográficad de la Formación La Luna en el Sector de El Tablazo, Valle Medio Del Magdalena. 10th Simposio Bolivariano Exploracion Petrolera en las Cuencas Subandinas. Session: Aprendiendo del Pasado - Mirando Hacia El Futuro. ACGGP.

Bernard, S., Wirth, R., Schreiber, A., Bowen, L., Aplin, A.C., Mathia, E.J., Schulz, H.M. \& Horsfield, B. (2013). FIBSEM and TEM investigations of an organic-rich shale maturation series from the lower Toarcian Posidonia Shale, Germany: Nanoscale pore system and fluid-rock interactions. In: Camp, W., Diaz, E., Wawak, B. (Eds.), Electron Microscopy of Shale Hydrocarbon Reservoirs. AAPG Memoir 102: 53-66.

Bjorlykke, K. (2013). Petroleum Geoscience from Sedimentary Environments to Rock Physics. Springer, p. 508.

Boles, J.R. \& Franks, S.G. (1979). Clay diagenesis in Wilcox sandstones of southwestem Texas: Implications of smectite diagenesis on sandstone cementation. Journal of Sedimentary Petrology 49: 55-70.

Brothers, L., Engel, M.H. \& Krooss, B.M. (1991). The effects of fluid flow through porous media on the distribution of organic compounds in a synthetic crude oil. Organic Geochemistry 17: 11-24.

Bruce, C.H. (1982). Relation of Illite/Smectite Diagenesis and Development of Structure in the Northern Gulf of Mexico Basin. Abstract, AAPG Bulletin 66 (9), pp.1443.

Casadiego, E. (2014). Caracterización de reservorios de gas shale integrando datos multiescala: Caso estudio Miembro Galembo, Sección Aguablanca, Cuenca del Valle Medio del Magdalena. Tesis de Maestría, Universidad Industrial de Santander, Colombia.

Chalmers, G.R.L., Bustin, R.M. \& Power, I.M. (2012). Characterization of gas shale pore systems by porosimetry, pycnometry, surface area, and field emission scanning electron microscopy/transmission electron microscopy image analyses: examples from the Barnett, Woodford, Haynesville, Marcellus, and Doig units. AAPG Bulletin 96 (6): 1099-1119.

Chen, Sh., Zhu, Y., Wang, H., Liu, H., Wei, W. \& Fang, J. (2011). Shale gas reservoir characterisation: A typical case in the southern Sichuan Basin of China. Energy 36: 6609-6616.

Curtis, J.B. (2002). Fractured shale-gas systems. AAPG Bulletin, 86 (11): 1921-1938.

Curtis, M.E., Ambrose, R.J., Sondergeld, C.H. \& Rai, Ch.S. (2012a). Microstructural investigation of gas shales in two and three dimensions using nanometer-scale resolution imaging. AAPG Bulletin 96 (4): 665-677.

Curtis, M.E., Cardott, B.J., Sondergeld, C.H. \& Rai, Ch.S. (2012b). Development of organic porosity in the Woodford Shale with increasing thermal maturity. International Journal of Coal Geology 103: 26-31.

Day-Stirrat, R., Aplin, A., Środoń, J. \& Van der Pluijm, B. (2008). Diagenetic reorientation of phyllosilicate minerals in Paleogene mudstones of the Podhale Basin, southern Poland. Clays and Clay Minerals 56: 100-111. 
Delle Piane, C., Almqvist, B.S.G., MacRae, C.M., Torpy, A., Mory, A.J. \& Dewhurst, D.N. (2015). Texture and diagenesis of Ordovician shale from the Canning Basin, Western Australia: Implications for elastic anisotropy and geomechanical properties. Marine and Petroleum Geology 59: $56-71$.

Gale, J.F.W. \& Holder, J. (2010). Natural fractures in some U.S. shales and their importance for gas production. Geological Society, London, Petroleum Geology Conference Series 7: 1131-1140.

Garner, A.H. (1926). Suggested nomenclature and correlation of the geological formations in Venezuela. American Institute of Mining and Metallurgy Engineers Transactions 1: 677 684.

Guo, Ch., Bai, B., Wei, M., He, X. \& Wu, Y.-S. (2013). Study on Gas Permeability in Nano Pores of Shale Gas Reservoirs. Colorado School of Mines SPE 167179 (1-11).

Hedberg, H.D. \& Sass, L.C. (1937). Synopsis de las formaciones geológicas de la parte occidental de la Cuenca de Maracaibo, Venezuela. Servicio Técnico de Geología y Minería, Caracas, Boletín de Geología y Mineralogía (Venezuela) 2-4: 83-84.

Hill, R.J., Zhang, E., Katz, B.J. \& Tang, Y. (2007). Modeling of gas generation from the Barnett shale, Fort Worth Basin, Texas. AAPG Bulletin 91 (4): 501-521.

Ho, N., Peacor, D. \& Van der Pluijm, B. (1999). Preferred orientation of phyllosilicates in Gulf Coast mudstones and relation to the smectite-illite transition. Clays and Clay Minerals 47: 495-504.

Hubach, E. (1957). Estratigrafía de la Sabana de Bogotá y alrededores. Instituto Geológico Nacional, Boletín Geológico 5 (2): 93-112.

Jarvie, D., Hill, R.J., Ruble, T.E. \& Pollastro, R.M. (2007). Unconventional shale-gas systems: The Mississippian Barnett Shale of north-central Texas as one model for thermogenic shale-gas assessment. AAPG Bulletin 91 (4): 475-499.

Jensen, L.A., Sanchez-Ferrer, F., Pliego-Vidal, E., Goudy, C. \& Kertznus, V. (2013). Unconventional exploration potential of the Colombian basins: Perspectives from regional geology and structural evolution. AAPG International Conference (Cartagena, Colombia, 9/8-11/2013). Abstracts.

Jiao, K., Yao, S., Liua, Ch., Gao, Y., Wua, H., Li, M. \& Tang, Z. (2014). The characterization and quantitative analysis of nanopores in unconventional gas reservoirs utilizing FESEM-FIB and image processing: An example from the lower Silurian Longmaxi Shale, upper Yangtze region, China. International Journal of Coal Geology 128-129: 1-11.

Josh, M., Esteban, L., Delle Piane, C., Sarout, J., Dewhurst, D.N. \& Clennell M.B. (2012). Laboratory characterisation of shale properties. Journal of Petroleum Science and Engineering 88-89: 107-124.

Kingston, D., Dishroon, C. \& Williams, P. (1983). Global basin classification system: AAPG Bulletin 67 (12): 2175-2213.

Lafargue, E. \& Barker, C. (1988). Effect of water washing on crude oil compositions. AAPG Bulletin 72 (3): 263-276.
Lash, G.G. \& Blood, D. (2004). Geochemical and textural evidence for Early (shallow) diagenetic growth of stratigraphically confined carbonate concretions, Upper Devonian Rhinestreet black shale, western New York. Chemical Geology 206 (3-4): 407-424.

Lee, D., Herman, J.D., Elsworth, D., Kim, H.T. \& Lee, H.S. (2011). A critical evaluation of unconventional gas recovery from the Marcellus Shale, Northeastern United States. KSCE Journal of Civil Engineering 15 (4): 679-687.

Loucks, R.G., Reed, R.M., Ruppel, S.C. \& Jarvie, D.M. (2009). Morphology, genesis, and distribution of nanometer-scale pores in siliceous mudstones of the Mississippian Barnett Shale. Journal of Sedimentary Research 79: 848-861.

Loucks, R.G., Reed, R.M., Ruppel, S.C. \& Hammes, U. (2012). Spectrum of pore types and networks in mudrocks and a descriptive classification for matrix-related mudrock pores. AAPG Bulletin 96 (6): 1071-1098.

Lu, X.-C., Li, F.-C. \& Watson, A.T. (1995). Adsorption measurements in Devonian shales. Fuel 74: 599-603.

Meulbroek, P., Cathles, L.M. \& Whelan, J. (1998). Phase fractionation in South Eugene Island Block 330. Organic Geochemistry 29: 223-239.

Milliken, K.L. \& Reed, R.M. (2010). Multiple causes of diagenetic fabric anisotropy in weakly consolidated mud, Nankai Accretionary Prism, IODP Expedition 316: Journal of Structural Geology 32: 1887-1898.

Milliken, K.L., Rudnicki, M., Awwiller, D.N. \& Zhang, T. (2013). Organic matter-hosted pore system, Marcellus Formation (Devonian), Pennsylvania. AAPG Bulletin 97 (2): $177-200$.

Modica, C.J. \& Lapierre, S.G. (2012). Estimation of kerogen porosity in source rocks as a function of thermal transformation: example from the Mowry Shale in the Powder River Basin of Wyoming. AAPG Bulletin 96 (1): 87-108.

Mondol, N.H., Bjorlykke, K., Jahren, J. \& Hoeg, K. (2007). Experimental mechanical compaction of clay mineral aggregates e changes in physical properties of mudstones during burial. Marine and Petroleum Geology 24: 289-311.

Montgomery, S. (1992). Petroleum potential of Upper and Middle Magdalena basins, Colombia. Petroleum Frontiers 9 (3), 67p.

Montgomery, S.L., Jarvie, D.M., Bowker, K.A. \& Pollastro, R.M. (2005). Mississippian Barnett Shale, FortWorth Basin, north-central Texas: gas-shale play with multitrillion cubic foot potential. AAPG Bulletin 89 (2): 155-175.

Moore, C.H. (1997). Carbonate diagenesis and porosity. Developments in Sedimentology 46, 338p.

Morales, L.G., Podesta, D.J., Hatfield, W.C., Tanner, H., Jones, S.H., Barker, M.H., O’Donoghue, D.J., Mohler, C.E., Dubois, E.P., Jacobs, C. \& Goss, C.R. (1958). General Geology and oil occurrences of the Middle Magdalena Valley, Colombia. In: Weeks, L.G. (Eds.), Habitat of Oil Symposium. AAPG 41: 641-695.

O'Brien, N.R. \& Slatt, R.M. (1990). The fabrics of shales and mudstone; an overview. In: Burst, J.F., Johns W.D. (chairs). Clay Minerals Society, 27th annual meeting, program and abstracts: Clay Minerals Annual Conference 27, 99p. 
Rangel, A., Giraldo, B., Munar, R., Olaya, I., García, M., Gutierrez, J., Parra, P. \& Niño, Ch. $\left(2000^{a}\right)$. Estratigrafía química y facies orgánicas del Terciario Inferior y Cretácico Superior del Piedemonte Llanero y Valle Oriental del Magdalena. Internal Report ECOPETROL- ICP.

Rangel, A., Parra, P. \& Niño, C. (2000b). The La Luna Formation: chemostratigraphy and organic facies in the Middle Magdalena Basin. Organic Geochemistry 31 (12): 1267-1284.

Ramón, J.C., Dzou, L. \& Giraldo, B. (1997). Geochemical evaluation of the Middle Magdalena Basin, Colombia. CT\&F - Ciencia, Tecnología y Futuro 1 (3): 47-66.

Ramon, J.C. \& Dzou, L.I. (1999). Petroleum geochemistry of the Middle Magadalena Valley: Colombia. Organic Geochemitry 30 (4): 249-266.

Reyes, J.P. (1996). Oil potential of the Cretacic megasequence and associated oil families in the Middle Magdalena Valley, Colombia. Memorias del V Congreso Latinoamericano de Geoquímica Orgánica, Cancún, p.105.

Reyes, J.P., Fajardo, A., Mantilla, M. \& Barragán, M. (2000). Secuencia Calcárea del Cretáceo del Valle Medio Del Magdalena, Colombia. Una Nueva Frontera Exploratoria ACGGP.

Ritter, U. (2003). Solubility of petroleum compounds in kerogen: implications for petroleum expulsion. Organic Geochemistry 34: 319-326.

Ritter, U. \& Grover, A. (2005). Adsorption of petroleum compounds in vitrinite: implications for petroleum expulsion from coal. International Journal of Coal Geology 62: 183-191.

Rodríguez, J.C. (2013). Challenges and opportunities for the development of Shale resources in Colombia. MSc thesis, The University of Texas, Austin.

Romero-Sarmiento, M.F., Ducros, M., Carpentier, B., Lorant, F., Cacas, M. Ch., Pegaz-Fiornet, S., Wolf, S., Rohais, S. \& Moretti, I. (2013). Quantitative evaluation of TOC, organic porosity and gas retention distribution in a gas shale play using petroleum system modeling: Application to the Mississippian Barnett Shale. Marine and Petroleum Geology 45: 315-330.

Romero-Sarmiento, M.F., Rouzaud, J.N., Bernard, S., Deldicque, D., Thomas, M. \& Littke, R. (2014). Evolution of Barnett Shale organic carbon structure and nanostructure with increasing maturation. Organic Geochemistry 71: 7-16.

Ross, D.J.K. \& Bustin, R.M. (2009). The importance of shale composition and pore structure upon gas storage potential of shale gas reservoirs. Marine and Petroleum Geology 26: 916-927.

Royero, J.M. \& Clavijo, J. (2001). Memoria Explicativa Mapa Geológico Generalizado Departamento de Santander, escala 1:400.00. INGEOMINAS, Bogotá.

Schamel, S. (1991). Middle and Upper Magdalena Basins, Colombia. In: Biddle, K.T. (Eds.), Active Margin Basins. AAPG Memoir 52: 283-301.
Slatt, R.M. \& O'Brien, N.R. (2011). Pore types in the Barnett and Woodford gas shales: contribution to understanding gas storage and migration pathways in fine grained rocks. AAPG Bulletin 95 (12): 2017-2030.

Slatt, R.M., Philip, P., Abousleiman, Y., Singh, P., Perez, R., Portas, K., Marfurt, J., Madrid-Arroyo, N., O’Brien, E., Eslinger, V. \& Baruch, E. (2012). Pore-to-regional-scale, integrated characterization workflow for unconventional gas shales. In: Breyer, J. (Eds.), Shale reservoirs-Giant resources for the 21st century, AAPG Memoir 97: 127-150.

Sun, Y., Lu, X.C., Shu, L.S. \$\& Liu, H. (2008). Observation \& determination of the nano-sized particle layer in rocks and its geological significance. Journal of Geomechanics 14 (1): $37-44$.

Torres, E.J. (2013). Unconventional gas shale assessment of La Luna Formation in the central and south areas of the Middle Magdalena Valley Basin, Colombia. MSc thesis, University of Oklahoma, Norman.

Torres, E.J., Slatt, R.M., Philp, P. Brien, N.R.O. \& Rodríguez, H.L. (2015). Unconventional resources assessment of La Luna Formation in the Middle Magdalena Valley Basin, Colombia. AAPG Annual Convention \& Exhibition, Denver, Colorado, May 31-June 3, 2015.

Vermylen, J.P. (2011). Geomechanical Studies of the Barnett Shale, Texas, USA. PhD thesis, Stanford University, Stanford.

Ward D.E., Goldsmith R., Jimeno V., Cruz B.J., Restrepo H. \& Gómez, R. (1969). Mapa Geológico del Cuadrángulo H-12, Bucaramanga, Colombia. Ingeominas.

Warlick, D. (2006). Gas shale and CBM development in North America. Oil and Gas Financial Journal 3 (11): 1-5.

Weniger, P., Kalkreuth, W., Busch, A. \& Krooss, B.M. (2010). High-pressure methane and carbon dioxide sorption on coal and shale samples from the Paraná Basin, Brazil. International Journal of Coal Geology 84: 190-205.

Williams, K.E. (2012). The Permeability of Overpressure Shale Seals and of Source Rock Reservoirs is the Same. AAPG 2012 Annual Convention and Exhibition, Long Beach, California, 22-25 April.

Yao, S.P., Jiao, K., Zhang, K., Hu, W.X., Ding, H., Li, M.Ch. \& Pei, W.M. (2011). An atomic force microscopy study of coal nanopore structure. Chinese Science Bulletin 56 (25): 2706-2712.

Zhang, T.W., Ellis, G.S., Rupple, S.C., Milliken, K. \& Yang, R. (2012). Effect of organic matter type and thermal maturity on methane adsorption in shale-gas systems. Organic Geochemistry 47: 120-131.

Zumberge, J. (1984). Source Rocks of the La Luna Formation (Upper Cretaceous) in the Middle Magdalena Valley, Colombia. In: Palacas J. (Eds.), Petroleum Geochemistry and Source Rock Potential of Carbonate Rocks. AAPG Studies in Geology 18: 127-133.

Zumberge, J., Ferworn, K. \& Brown, S. (2012). Isotopic reversal ('rollover') in shale gases produced from the Mississippian Barnett and Fayetteville formations. Marine and Petroleum Geology 31: 43-52. 